\author{
JOSÉ ARMANDO HERNÁNDEZ SOUBERVIELLE \\ EL COLEGIO DE SAN LUIS
}

\title{
Templos pleurantes del norte Esgrafiado de tradición mudéjar en cuatro iglesias del septentrión novohispano
}

\section{De la técnica mudéjar a su pervivencia en el Nuevo Mundo}

\begin{abstract}
$\mathrm{L}$ a herencia del arte mudéjar en Espańa es un tema que se ha abordado ampliamente, en particular lo que se refiere a su influjo en la arquitectura y en las artes decorativas espańolas del medioevo. En este sentido, los estudios abarcan desde las obras arquitectónicas más complejas hasta los rastros ornamentales y técnicos de origen andalusí más simples que, por su alto efecto decorativo y bajo costo, adoptó la Espańa conquistada ${ }^{\mathrm{I}}$ a manera de continuación de una tradición morisca ejecutada ya no sólo por los mudéjares, sino también por los cristianos. La extensión y la diversidad geográfica española, además de las diferentes concentraciones de moros en cada región, dieron como resultado una amplia gama de variantes en las manifestaciones de lo que se denomina arte mudéjar. ${ }^{2}$ Sobre este asunto las discusiones siguen vigentes, aunque con el decurso de los años el término se ha decantado y ha perdido toda la carga étnica inicial para referirse únicamente a la pervivencia de
\end{abstract}

I. Rafael Ruiz Alonso, Evolución histórica del esgrafiado en España (discurso de ingreso a la Real Academia de Historia y Arte de San Quirce, pronunciado el 28 de noviembre de 2008), I48-I49.

2. Esteban Sarasa Sánchez, "La sociedad mudéjar", en Arte mudéjar en Aragón, León, Castilla, Extremadura y Andalucia, coord. María del Carmen Lacarra Ducay (Zaragoza: Institución Fernando el Católico, 2006), 8-9. 
arte andalusí en la España cristiana, ${ }^{3}$ un arte considerado, por otro lado, de síntesis. ${ }^{4}$ La coincidencia de la conquista del reino nazarí de Granada con el descubrimiento de América en 1492 provocó que ese conjunto de elementos y sentido estéticos, que la España cristiana había tomado del mundo andalusí para enriquecer su propio vocabulario, llegara a las tierras recién descubiertas, gracias a los artesanos espańoles.

Si bien el mudéjar como expresión artística es característicamente hispánico, 5 también lo es que su influencia se dejara notar aquende el mar. No obstante, mientras que en España la discusión respecto al arte mudéjar está aún vigente y se ha documentado de manera amplia, en el caso de México los estudios relativos a los rastros mudéjares en lo que fuera la Nueva España son $\operatorname{pocos}^{6}$ y se han enfocado sobre todo en señalar la presencia de elementos blancos en la arquitectura y la carpintería: artesonados, alfarjes y armaduras en las techumbres de las iglesias del siglo Xvi principalmente; ${ }^{7}$ en tanto que respecto de la arquitectura de piedra, destacan particularidades, como el uso de pilares ochavados, ${ }^{8}$ ventanas geminadas, torreones, bóvedas sobre arcos cruzados, fuentes y sistemas hidráulicos, entre otros. Especial atención han merecido también las artes decorativas, como el uso del azulejo en la arquitectura novohispana de la región Puebla-Tlaxcala (en particular); técnica ésta de clara influencia mudéjar que pervive bajo el nombre de talavera (por Talavera de

3. Gonzalo M. Borrás Gualis, "El islam. De Córdoba al mudéjar", en Manuel Bendala Galán, Isidro Bango Torviso et al., Manual del Arte Español (Madrid: Sílex, 2003), 287.

4. Rafael López Guzmán, Arquitectura mudéjar: del sincretismo medieval a las alternativas hispanoamericanas (Madrid: Cátedra, 2000), I6.

5. Borrás Gualis, "El islam", 289.

6. El trabajo pionero en México lo hizo Manuel Toussaint (Arte mudéjar en América [México: Porrúa, 1946]) y posteriormente se han hecho trabajos que han tratado de seguir los supuestos iniciales; en tanto que diversos investigadores españoles también se han acercado al tema del mudéjar en Hispanoamérica. Véase por ejemplo Gloria Espinosa Spínola, Rafael López Guzmán et al., Arquitectura y carpintería mudéjar en Nueva España (México: Grupo Azabache, 1992).

7. Francisco de la Maza, La ciudad de México en el siglo XVII (México: Fondo de Cultura Económica, 1968), I0; Guadalupe Avilés Moreno, "La carpintería mudéjar en Nueva España en el siglo xvi", en Actas del II Simposio de Mudejarismo (Teruel: Consejo Superior de Investigaciones Científicas, 1982), 333-340.

8. Obtuve referencias sueltas y cuando es así éstas están vinculadas a esa mezcla entre gótica y mudéjar, florecida en Espańa. Véase por ejemplo, Cecilia Gutiérrez Arriola, "El convento de Nuestra Seńora de la Asunción de Tlaxcala en el siglo xvi. Notas sobre un dibujo de Diego Muñoz Camargo", Anales del Instituto de Investigaciones Estéticas XIX, núm. 7I (1997): 28. 
la Reina, España). ${ }^{9}$ Fuera de estos aspectos (arquitectura lignaria, arquitectura en piedra y técnicas decorativas) otros temas vinculados con la presencia del mudéjar en el arte novohispano han merecido poca atención. Los estudios realizados en México se han centrado en las obras más representativas en determinadas regiones del país, ${ }^{10}$ así como en las manifestaciones posteriores a la emancipación de los dominios americanos de España en forma de pervivencias y revivals, como lo fue el llamado neomudejarismo común tanto en la Península como en México en el siglo XIX. ${ }^{\text {II }}$ Baste citar la atención que ha recibido el pabellón morisco diseñado en I885 por el arquitecto Ramón Ibarrola para la Exposición Internacional de Nueva Orleáns y que terminó engalanando la Alameda central de la ciudad de México hasta su cambio de sitio en I9Io.

Por su parte, los estudios españoles sobre la influencia mudéjar en el llamado Nuevo Mundo, o bien reducen lo hecho en América a simples rasgos formales desarraigados ya de la herencia mudéjar, o le atribuyen el carácter de reminiscencias propias de un proceso de transculturación en el que no todo lo que tiene características comunes con este arte, es tal; ${ }^{\mathrm{I2}}$ queda así la discusión nuevamente abierta pero poco explorada. Si bien se han hecho intentos interdisciplinarios y transoceánicos ${ }^{13}$ por comprender el arte mudéjar y su influencia en Hispanoamérica, el tema sigue siendo una veta importante de trabajo.

A lo anterior debo añadir que los estudios realizados hasta ahora sobre la influencia del arte y las técnicas mudéjares en el mundo novohispano se han enfocado en las grandes obras, o al menos en las más representativas y evidentes, y dejan de lado el estudio de ejemplos más sencillos, menos notorios, producidos en otras latitudes dentro de la geografía novohispana, pero que de igual manera dan cuenta de la sucesión y progresión de técnicas y manifestaciones visuales

9. Manuel González Galván, "Modalidades del barroco mexicano", Anales del Instituto de Investigaciones Estéticas VIII, núm. 30 (I96I): 43-44.

Io. De hecho en algunas obras se ha hablado de la "geografía del mudéjar" en territorio mexicano. Véase López Guzmán, Arquitectura y carpintería, II6-I24.

II. Elisa García Barragán, "Supervivencias mudéjares y presencias orientalistas en la arquitectura mexicana”, Anales del Instituto de Investigaciones Estéticas XIII, núm. 45 (1976): I37.

I2. Rafael López Guzmán, "Arquitectura mudéjar y su proyección en América”, en El saber en Al-Andalus, ed. Pedro Martínez Montavez (Universidad de Sevilla/Fundación El Monte, 2OII), 270.

I3. Véase, en particular, López Guzmán, Arquitectura mudéjar. Una obra importante en este sentido, no obstante su poca extensión, es Sintesis de culturas. Mudéjar: itinerario cultural del mudéjar en México, eds. Juan Benito Artigas, Gloria Espinosa Spínola et al. (Granada: Junta de Andalucía/Consejería de Cultura/Fundación El Legado Andalusí, 2002). 
que hunden sus raíces en el mundo andalusí, pasando por la España conquistada hasta llegar en forma de trazos simples al Nuevo Mundo. Nos referimos en específico a la decoración esgrafiada y agramilada de influencia mudéjar que aún podemos encontrar en los muros de algunas construcciones que se han ignorado, por no presentar la complejidad y plasticidad de otros patrones decorativos, como lo son los relieves de argamasa que semejan lacerías y formas geométricas complejas a la manera de las empleadas en los artesonados (véanse los muros del ex colegio jesuita de Tepotzotlán [fig. I] o los muros exteriores del antiguo convento de carmelitas en Churubusco).

Mientras que en España en años recientes hay un renovado interés por el tema de los esgrafiados (desde el punto de vista de la rehabilitación patrimonial, la enseñanza, la creación y el estudio histórico), ${ }^{14}$ en México, en lo que respecta a los casos de esgrafiados novohispanos, poco se ha hecho por acercarse al tema, más aún cuando — como en los casos que aquí expongo-o bien no forman parte de un conjunto arquitectónico de gran relevancia o empequeñecen ante éste; a lo que se suma el desconocimiento de su existencia y el que su sencillez o falta de "calidad técnica" haya merecido la poca o nula atención de los investigadores.

Es en función de esto último que me parece importante señalar los ejemplos de decoración de raigambre mudéjar que aún se pueden observar en cuatro construcciones del septentrión novohispano y que conforman, aunque corto, un singular corpus de análisis puesto que todas ellas pertenecen al siglo xviII; esto es, muy lejos ya del foco de influencia que el trasplante de estas formas artísticas tuvo en los siglos XVI y xvir. Agregaré a lo anterior que, hasta el momento, no se ha trabajado la influencia o legado técnico de tradición mudéjar en poblaciones de la frontera norte del virreinato de la Nueva España. ${ }^{15}$ Por último, el presente trabajo pretende, al tiempo de dar a conocer estos patrones decorativos hasta ahora olvidados, ser un medio de rescate documental puesto que los vestigios que subsisten no se encuentran en condiciones de mantenerse por mucho tiempo más, y tienden a desaparecer porque los materiales están sufriendo el embate de la intemperie, sumado a la poca atención que se les ha brindado.

I4. Ruiz Alonso, Evolución histórica del esgrafiado, I47.

15. De hecho, dentro de la "geografía mudéjar", el actual estado de Hidalgo es lo más al norte que se ha trabajado. Véase López Guzmán, Arquitectura y carpintería, II6-I24. 


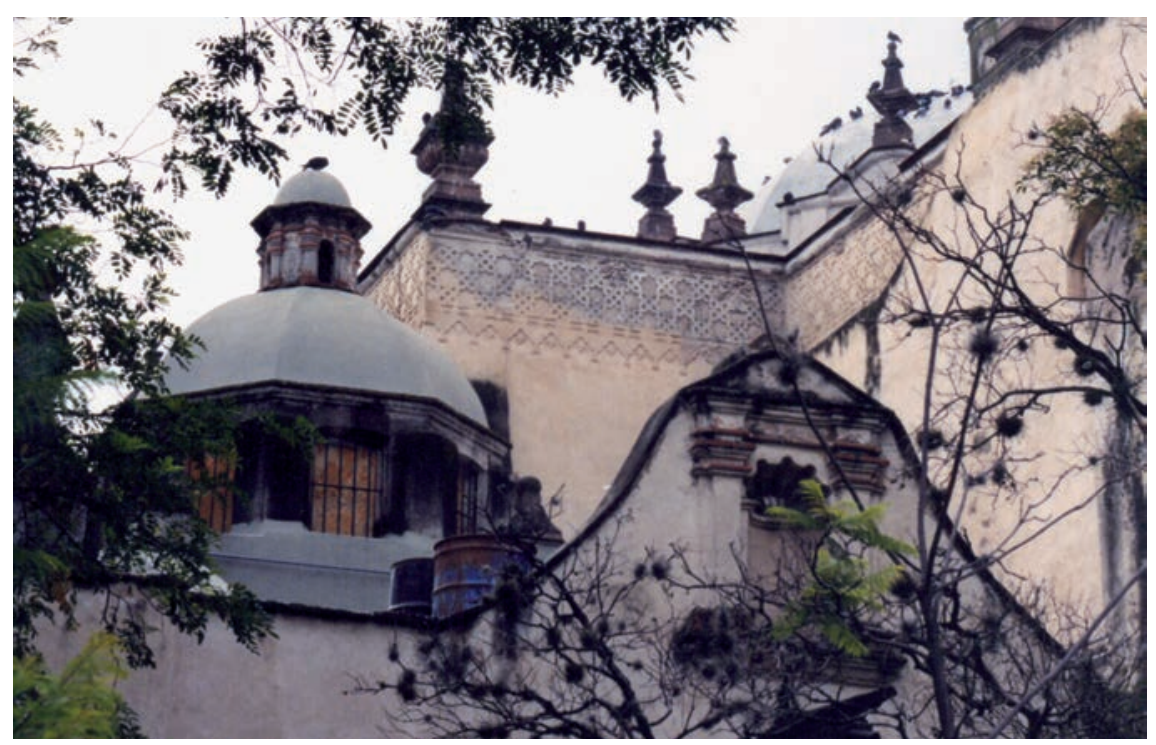

I. Antiguo Colegio Noviciado Jesuita de Tepotzotlán (siglo xviII), Estado de México. Foto del autor, 2006. Conaculta-INAH-MÉx. "Reproducción autorizada por el Instituto Nacional de Antropología e Historia”.

Las muestras que me ocupan en este artículo corresponden a una serie de edificaciones ubicadas en la antigua frontera septentrional de la Nueva España (la frontera chichimeca); en específico en una zona rural y en dos reales de minas, en los actuales estados de San Luis Potosí y Zacatecas.

Acompańé el título de este texto con el adjetivo pleurantes, ${ }^{16}$ puesto que las soluciones formales, encontradas en muros exteriores de los edificios, parecen lágrimas o gotas que los cubren y, si bien éste es un término empleado para definir esculturas sollozantes vinculadas a la arquitectura funeraria, lo adopto ya que funciona conceptualmente para señalar esta peculiaridad formal. Las decoraciones sollozantes —o pleurantes - de estos templos, lejos de la carga simbólica que pudieran tener (sobre la cual no me detendré en esta ocasión), son producto del cruce de tecnologías y formas de raigambre andalusí arribadas a este territorio y que pervivieron hasta bien entrado el siglo XVIII.

I6. Del francés pleurant, esto es, "en llanto", "llorantes". 
Ahora bien, para poder dar paso al análisis resulta necesario profundizar un poco más respecto al significado del mudéjar en la historia del arte hispanoamericano, y más específicamente, a lo que su legado supone para México.

La convivencia cultural entre individuos de la religión islámica dentro de jurisdicciones cristianas en España influyó en ambas vías de forma benéfica y enriquecedora. ${ }^{17}$ Este hecho dio como resultado el desarrollo de una serie de técnicas ${ }^{18}$ comunes, con doble origen, en la cual encontraron cabida tanto elementos cristianos como musulmanes, desprovistos ya de toda carga ideológica. ${ }^{19}$ Éstos arribaron de forma contemporánea a los territorios recién descubiertos, toda vez que, al iniciarse la relación entre España y América, la cultura andalusí había dejado ya su impronta, amplia y profunda, en la cultura española. ${ }^{20}$ Rafael López Guzmán ha definido el arte mudéjar en Hispanoamérica como una técnica constructiva (esencialmente habla de la carpintería), rápida, barata y con calidad estética; lo cual la hizo de utilidad y le dio validez para el proceso de aculturación que la monarquía absoluta de los Austria pretendía implantar en los territorios americanos. Es decir, "la respuesta inmediata de un Estado absoluto ante la necesidad de ocupación del territorio", ${ }^{21}$ empleada tanto en edificaciones institucionales (parroquias, conventos, hospitales, entre otros) ${ }^{22}$ de los barrios eminentemente populares como en ciudades y villas de menor entidad. ¿Por qué considerar esto? Simplemente porque la respuesta más sencilla de aculturación por medio de las formas, y ensayada con éxito en el reino de Granada tras la entrega de ésta en I492, había sido la tecnología mudéjar, ${ }^{23}$ lo que permite entender su rápida inclusión en

17. López Guzmán, Arquitectura y carpintería, I5.

18. Se entiende por técnica aquí el conjunto de procedimientos y recursos materiales de que se sirvió este arte, de los cuales evidentemente se desprendería la habilidad para ejecutar tales procesos y utilizar determinados materiales.

19. López Guzmán, Arquitectura y carpintería, 15.

20. López Guzmán, Arquitectura mudéjar, 424.

2I. Rafael López Guzmán, "La arquitectura mudéjar: situación historiográfica y nuevos planteamientos", en Manuel Toussaint. Su proyección en la historia del arte mexicano (México: Universidad Nacional Autónoma de México-Instituto de Investigaciones Estéticas, 1993), I29. En este sentido, debemos considerar el carácter decorativo del mudéjar, mismo que sirvió tanto en Espańa como en América para cubrir la pobreza de los materiales constructivos.

22. De hecho, la arquitectura institucional fue un mecanismo de aculturación altamente eficaz, ya que al transformar el territorio creaba una nueva imagen del mismo. López Guzmán, Arquitectura mudéjar, 4I9.

23. López Guzmán, Arquitectura y carpintería, 24. 
territorios americanos. Ahora bien, se ha considerado que el mudéjar en América se desarrolló con mayor eficacia a partir de la conquista de México en I52I, al tomar el español verdadera conciencia de la magnitud de la empresa que tenía por delante, a lo largo del siglo xvi. ${ }^{24}$

Este trasplante o transferencia de formas artísticas españolas a México tuvo su apogeo en los primeros siglos bajo el gobierno español, y se manifestó particularmente en la decoración exterior y en la carpintería de lo blanco. ${ }^{25}$ Cabe destacar que, a diferencia de las soluciones españolas, donde la decoración mudéjar cubría la pobreza y fragilidad de los materiales exteriores (yeso, madera, ladrillo), ${ }^{26}$ los ejemplos en México más documentados no presentan una construcción frágil o con materiales perecederos, sino todo lo contrario; con lo cual la transferencia de técnicas se limitó a ello. Prueba de esto son las soluciones de raigambre mudéjar que encontramos en el valle de México, Puebla y Tlaxcala, Michoacán e Hidalgo y, en menor escala, en Chiapas y Oaxaca, pertenecientes a los siglos XVI y XVII. ${ }^{27}$ Sin embargo, estas formas habrían de llegar, aunque desfasadas en tiempo, al norte, de forma tal que en el siglo XviII existían aún rastros de técnicas popularizadas (ya no como proyecto aculturador, sino como meras pervivencias formales) que siguieron empleando patrones decorativos mudéjares, ${ }^{28} \mathrm{y}$ es ahí donde me detengo para dar paso a la parte central de este trabajo.

\section{Un legado que llegó hasta el norte}

La fundación del pueblo de españoles de San Luis Potosíi ${ }^{29}$ en 1592 obedeció, entre otros factores, al descubrimiento de ricas vetas de mineral en el cerro de San Pedro. ${ }^{30}$ Esto propició el pronto establecimiento de poblaciones cerca-

24. López Guzmán, Arquitectura mudéjar, 419.

25. Rafael Cómez Ramos, Andalucía y México en el Renacimiento y barroco. Estudios de arte $y$ arquitectura (Sevilla: Biblioteca Guadalquivir, 199I), 9.

26. Cómez Ramos, Andalucía y México, I2.

27. López Guzmán, Arquitectura y carpintería, I09-168.

28. López Guzmán, Arquitectura mudéjar, 42I.

29. Actual capital del estado homónimo.

30. Previamente en este asentamiento se había establecido un pueblo de indígenas huachichiles hacia I588-1589, el cual se consolidó en I59I con la llegada de familias de indígenas tlaxcaltecas aculturados. Con el descubrimiento de mineral en el cerro de San Pedro hubo necesidad de establecer un pueblo de españoles, mismo que se asentó en la antigua fundación 
nas que en forma de pueblos y haciendas incipientes, poco a poco cambiaron el paisaje de la región.

La noticia de la recién descubierta riqueza mineral corrió como pólvora por todos los confines del virreinato y la monarquía hispánica, y atrajo a muchos que llegaron de los puntos más diversos a poblar la región. Nuevas vetas de mineral se encontraron hacia el norte del pueblo de San Luis Potosí, como fue el caso de la villa y minas de San Pedro, establecida en 1608 y que adquirió el rango de Real de Minas bajo el título de Guadalcázar en 1616. ${ }^{\mathrm{I}}$ Asimismo, a finales del siglo Xvi, a la par de haciendas de beneficio de metales, se fundaron también haciendas de abastecimiento, como la denominada Del Pozo, en el hoy municipio de Armadillo, la cual suministraba productos agrícolas y ganado a la región. Es en algunas edificaciones de estas dos fundaciones que he de concentrar mi trabajo.

\section{El esgrafiado de lágrimas en Pozo del Carmen}

Comenzaré por analizar la edificación más próxima a la cabecera municipal de San Luis Potosí. El primer caso es la iglesia de Pozo del Carmen, edificada en una antigua hacienda homónima localizada a 66 kilómetros de la capital del estado.

Desde su fundación a finales del siglo XvI, esta hacienda se especializó en la cría de ganado (en particular, menor), así como en productos agrícolas. Pasó por diversas manos en el decurso del siglo XVII, y terminó en manos de los regulares de la orden de carmelitas descalzos a mediados del siglo XVIII. ${ }^{32}$ Los del Carmelo habían llegado a la ciudad de San Luis Potosí entre 1733 y 1738 (aunque fundaron convento hasta 1747 cuando se les expidió cédula real con tal propósito), ${ }^{33}$ gracias en parte a las donaciones hechas vía testamentaria por Nicolás Fernando de Torres, rico minero y comerciante de San Luis Potosí, avecindado por entonces en Querétaro. Entre los bienes testados estaba la

indígena, que al haber sido desplazada terminó siendo pueblo de indios periféricos.

3I. En honor del virrey (I6I2-I62I) Diego Fernández de Córdoba, marqués de Guadalcázar.

32. Los carmelitas fueron dueños de ésta hasta I 847 cuando se vendió. Alfonso Martínez Rosales, El gran teatro de un pequeño mundo. El Carmen de San Luis Potosi, I732-1859 (México: El Colegio de México/Universidad Autónoma de San Luis Potosí, I985), I35.

33. Martínez Rosales, El gran teatro, I37-I38, I8I. 
hacienda de Pozo del Carmen por lo cual desde 1742 se sabe que se encontraba bajo administración carmelita. ${ }^{34}$

Un detalle que hace única esta hacienda, ubicada en el norte de la jurisdicción de San Luis Potosí, y cuya construcción corresponde ya a la administración carmelitana, es su vasta y compleja red hidráulica. Por medio de ésta se captaba y aprovisionaba la hacienda tanto de agua pluvial como subterránea. La hacienda de Pozo del Carmen, a partir de un sistema de qanats o foggaras (de clara influencia morisca), ${ }^{35}$ esto es, galerías filtrantes horizontales también conocidas como "tajos", "socavones", "viajes" o "minas de agua", ${ }^{6}$ contó con una serie de aljibes, caños, norias, lavaderos y canales subterráneos que llevaban agua hasta la hacienda. La red hidráulica se abastecía de una represa en el costado suroeste de la hacienda, la cual a su vez se alimenta por una foggara. Desde dicha represa se conducía el agua a toda la propiedad por medio de un sistema de canales, ${ }^{37}$ que bañaba los campos de labrantío, abastecía las redes para establos y caballerizas, y suministraba el líquido al interior de la hacienda. Cabe destacar la existencia de una galería de almacenamiento subterráneo que pasaba por debajo de la casa grande y aparentemente de la iglesia contigua, lo cual me hace pensar en un sistema climatizador de dichos edificios, además del almacenaje de agua con escasa evaporación. La compleja red hidráulica remite al tratado manuscrito de arquitectura del lego carmelita del siglo xviI, fray Andrés de San Miguel, el cual contenía todo un corpus sobre hidráulica y artesonados de clara influencia mudéjar. ${ }^{38}$

Fue hacia 1748 cuando se determinó que en los terrenos junto a la casa grande de la hacienda se erigiría una iglesia, la cual tomaría por modelo el tem-

34. Martínez Rosales, El gran teatro, I20.

35. Miquel Barceló, "La cuestión del hidraulismo andalusí", en El agua que no duerme. Fundamentos de la arqueología hidráulica andalusí, coords. Miquel Barceló, Helena Kirchner et al. (Sevilla: Fundación El Legado Andalusí, 1996), 31.

36. Cristina Martínez García y Herbert H. Eling, Jr., "Cambios, innovaciones y discontinuidades en los sistemas de riego por galería filtrante en Parras de la Fuente, Coahuila, México", en Agua y tierra en México, siglos XIX y XX, coords. Antonio Escobar Ohmstede, Martín Sánchez Rodríguez et al., vol. I (Zamora: Colegio de Michoacán/Colegio de San Luis, 2008), I27.

37. El elemento más emblemático de esta red hidráulica es una pieza arquitectónica conocida como el "baño de los carmelitas".

38. Obras de fray Andrés de San Miguel, introd., notas y versión paleográfica de Eduardo Báez Macías (México: Universidad Nacional Autónoma de México-Instituto de Investigaciones Estéticas, 1969). 


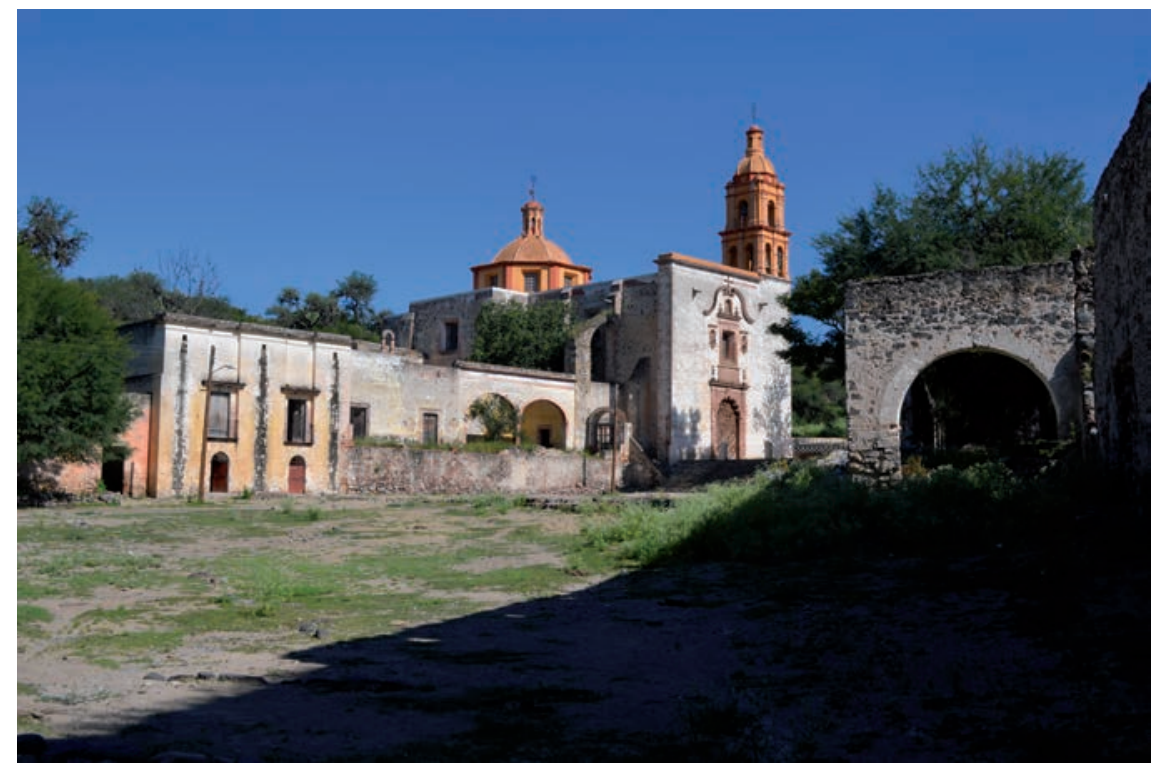

2. Hacienda e iglesia de Pozo del Carmen (siglo xvirI), Armadillo de los Infante, San Luis Potosí, México. Foto del autor, 20I3. Conaculta-INAH-MÉx. "Reproducción autorizada por el Instituto Nacional de Antropología e Historia".

plo del Carmen, levantado en la ciudad de San Luis Potosí, ${ }^{39}$ y es en ella en la que me detendré. En el conjunto hacendario se detectan diversas etapas constructivas; conviven edificaciones de los siglos XVIII y XIX e incluso de principios del siglo xx, cuando la producción decreció y la propiedad se fraccionó en ejidos. Sin embargo, la iglesia mantuvo las características de su edificación a mediados del siglo XviII. Ubicada en un eje oriente-poniente, la iglesia de Pozo del Carmen, de cruz latina, con cúpula en el crucero y torre en el costado norte, destaca por sus sólidos muros y contrafuertes (fig. 2). De su frontispicio vale decir que aun en su sencillez se aprecia el intento de vincularlo con la matriz citadina. De cantera rosada, la portada está compuesta por un arco de triunfo, de pilastras dóricas estriadas y adosadas al paramento; destaca en particular el intradós del arco de medio punto, del cual brotan tres pares de flores en roleo, que continúan una arquivolta decorada con motivos vegeta-

39. Martínez Rosales, El gran teatro, I27. 
3. Frontispicio de la iglesia de Pozo del Carmen, Armadillo de los Infante, San Luis Potosí, México. Foto del autor, 20I3. Conaculta-InaH-Méx. "Reproducción autorizada por el Instituto Nacional de Antropología e Historia."

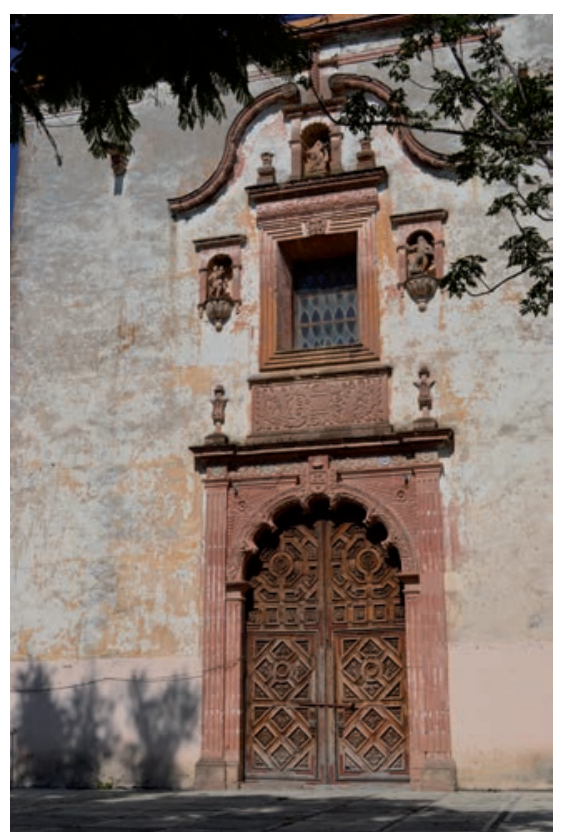

les. La clave del arco, con el escudo carmelita, rompe el arquitrabe y se inserta apenas en un friso, decorado también con motivos vegetales y florales. El cornisamento, igualmente sencillo, remata con sendas flores de lis de corte geométrico. Enseguida, una cartela de cantera rosada con motivos vegetales recuerda el año de $\mathbf{1 7 5 8}$, mismo que pudiera dar cuenta de la fecha de conclusión del edificio. Sobre la cartela hay una ventana coral flanqueada por sendos nichos. Remata el frontis un tercer nicho coronado con una cruz y flanqueado por una falsa cornisa ondulante (fig. 3).

Del decorado destacan, por supuesto, la magnífica puerta de madera de mezquite, labrada de manera semejante a la que se encuentra en el Carmen potosino, así como los restos de pintura de la portada: un descolorido, aunque aún rojizo almagre para la mayor parte del cuerpo arquitectónico del frontispicio, en tanto que rastros de azul, verde y ocre asoman en el friso. El resto de los muros presenta un enlucido pintado de ocre. Sin embargo, es el decorado de los paramentos laterales y del presbiterio lo que me interesa, ya que en ellos se descubren las reminiscencias decorativas mudéjares que se anticipan en el título de este trabajo. 


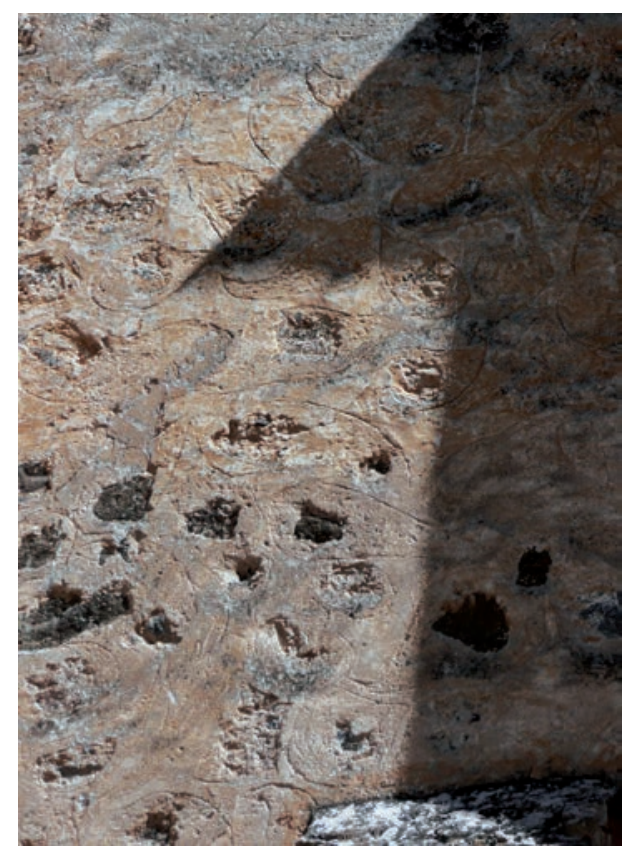

4. Esgrafiado de lágrima en el muro norte de la iglesia de Pozo del Carmen. Foto del autor, 2013.

La austera decoración de estos paramentos se basó principalmente en un esgrafiado ${ }^{40}$ de formas curvilíneas sobre un enlucido de yeso, ${ }^{4 \mathrm{I}}$ semejando gotas o lágrimas (figs. 4 y 5). Los dibujos hendidos no llevan un orden en sí mismos, más bien se trata de una aplicación anárquica, sin un patrón preconcebido; no existe ritmo claro o reconocible, sino un aparente desorden en su disposición. Es posible apreciar estas hendiduras tanto en el muro norte como en el del presbiterio. En algunas secciones de los muros, las lágrimas se aprecian

40. Técnica consistente en el trazo de dibujos empleando para ello un grafio o un instrumento punzante (un punzón o un buril, por ejemplo) sobre una superficie llana, haciendo saltar en algunos puntos la capa superficial y dejando así una marca hendida que bien puede o no develar el color de la siguiente capa.

4I. La técnica del esgrafiado está íntimamente ligada a un material mudéjar como es el yeso. Éste se utilizaba para enlucir muros interiores o exteriores que a su vez servían como base para decorados pictóricos o esgrafiados, previa aplicación de diferentes capas y colores que se levantaban con punzón. López Guzmán, Arquitectura mudéjar, 92. 
5. Esgrafiado de lágrima en la torre de la iglesia de Pozo del Carmen.

Foto del autor, 2013.

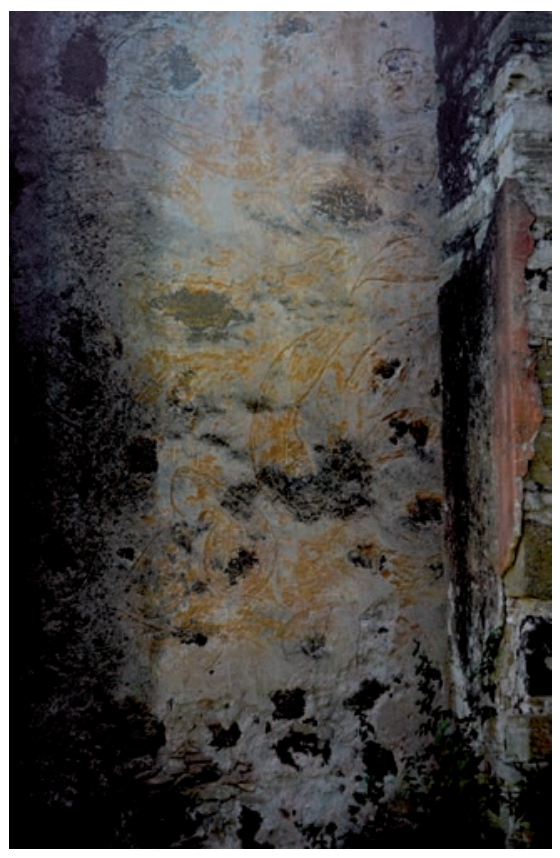

de forma simétrica, en otras extienden su cauda de forma caprichosa sobre los paramentos, y en algunas más, al juntar sus vértices, representan dibujos en forma de cuadrifolios, aunque esto último me parece fortuito. Las incisiones hechas sobre los muros no descubren color alguno bajo la capa ocre del enlucido, sino que sólo lo hienden. Simbólicamente, el aparente "sollozo" de los muros se vincula con la vocación hidráulica de la hacienda ya que las lágrimas hendidas escurren desde lo alto de los muros y terminan en el arranque de éstos, y conforman así un "escurrimiento" visual hacia las galerías horizontales que pasan por debajo de la hacienda y la iglesia. Estos motivos ornamentales están presentes también en otras partes de la hacienda, tanto en forma de esgrafiados como de pintura mural. Así, en las norias y en los tambores de algunos cupulines de pozos aparecen las mencionadas gotas y cuadrifolios (estos sí hechos ex profeso). Hay que recordar que la orden de carmelitas descalzos obligaba en sus prescripciones a que su arquitectura se desnudara de toda ornamentación excesiva, ${ }^{42}$ lo cual explicaría en parte la sencillez y

\section{Obras de fray Andrés de San Miguel, 48.}


adustez en el decorado de los muros y elementos arquitectónicos de la hacienda y su iglesia.

Analizar la forma y disposición de estas hendiduras me llevó a rastrear la fuente de inspiración de tales restos decorativos de tan sencilla factura, lo que me condujo hasta la España rural. Estas caprichosas formas curvilíneas tienen su antecedente en la decoración mudéjar conocida como esgrafiado de lágrima, gota o corazón. Si bien la técnica del esgrafiado no es privativa del arte andalusí —ya en la antigüedad romana existen ejemplos de ello—, fue ampliamente empleada en el contexto del arte califal, de forma tal que fue una de las técnicas predominantes para la decoración de paramentos tanto exteriores como interiores, como se atestigua en Castilla, León, Aragón, Segovia y por supuesto Andalucía. ${ }^{43}$ Importa destacar que tal técnica se continuó en el arte mudéjar una vez conquistados los reinos, de donde llegó al llamado Nuevo Mundo.

La virtud de la técnica del esgrafiado es que permitía que el muro quedara ornamentado (ocultando la sencillez o rugosidad del material de soporte) y, al mismo tiempo, protegía el exterior de manera económica. En cuanto a la forma de lágrima, o de gota, o acorazonada, que aparece en estos esgrafiados, tal parece que tiene su antecedente en una evolución de la técnica del rejuntado, ${ }^{44}$ de modo tal que el mortero empleado inicialmente para rellenar las llagas existentes en las juntas de las piedras de mampostería terminaría por ocultarlas por completo. Sobre este mortero se esgrafiaban inicialmente las formas irregulares de las piedras, que poco a poco adquirían forma de lágrimas, gotas o corazón, en tanto que el tendel permanecía liso. En algunos casos el esgrafiado desnudaba la piedra en su interior y en otros, como el caso de la hacienda del Pozo del Carmen, la piedra quedaba oculta bajo el revoque al ser los esgrafiados apenas una hendidura. Esta forma de esgrafiar los muros, por su facilidad y economía (no precisa el uso de plantillas o estarcidos) fue una de las más populares, por lo que este patrón se repitió en muchas zonas

43. Pedro J. Lavado Paradinas, "Artes decorativas mudéjares en Castilla y León”, en Arte mudéjar en Aragón, León, Castilla, Extremadura y Andalucia, coord. María del Carmen Lacarra Ducay (Zaragoza: Institución Fernando el Católico, 2006), I25, I30. También López Guzmán, Arquitectura mudéjar, 92.

44. Rafael Ruiz Alonso, "El esgrafiado en Segovia", tesis doctoral (Madrid: Universidad Complutense-Facultad de Geografía e Historia-Departamento de Arte Medieval, 2002), I87189. La técnica del rejuntado consiste en emplear mortero para emparejar las llagas entre piedras de la mampostería de un muro, no manchándolas sino creando un efecto de contraste entre piedra y juntura. 


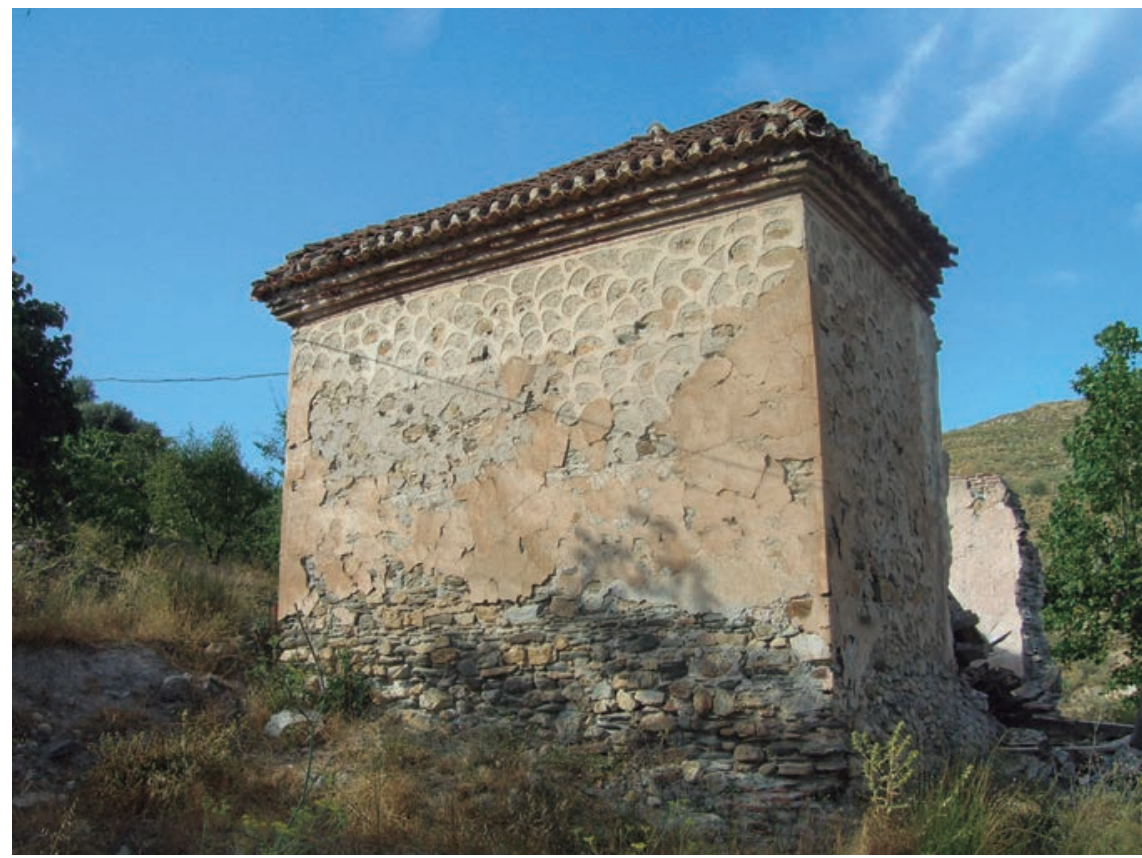

6. Esgrafiado de lágrima en la iglesia de Nuestra Señora del Rosario en Paterna del Río, Almería. Foto: Milagros Soler Cervantes, http://www.culturandalucia.com/ALmeria/Paterna_del_Rio/Iglesia_de_Ntra_Sr_del_Rosario_texto.htm, consultado el I3 de enero de 2015 .

rurales. ${ }^{45} \mathrm{He}$ encontrado ejemplos de estos esgrafiados en la región de Almería, de la cual se pueden mencionar tanto edificaciones religiosas, como la iglesia de Nuestra Señora del Rosario ubicada en la pedanía de Guarros, en el municipio de Paterna del Río de la zona de la Alpujarra (fig. 6), como civiles, por ejemplo, la torre nazarí en Santa Fe de Mondújar.

De esta forma, tanto las soluciones en cuanto a tecnología hídrica como el decorado esgrafiado de los paramentos de la iglesia y de otros cuerpos arquitectónicos de la hacienda de Pozo del Carmen hunden sus raíces en la tradición mudéjar de construir y ornamentar de forma económica, utilizando tanto técnicas constructivas como decorativas para ello. Los muros de Pozo del Carmen lloran así lágrimas de tradición mudéjar sobre tierras potosinas.

45. Ruiz Alonso, "El esgrafiado en Segovia", I87-I89. 


\section{Guadalcázar y su esgrafiado: \\ la incógnita de un mensaje cifrado entre lágrimas hendidas}

El mismo patrón decorativo de lágrimas esgrafiadas que acabo de documentar se presenta en los paramentos tanto de la iglesia de la Inmaculada Concepción (fig. 7) como de la parroquia (conocida también como templo de San Pedro) (fig. 8) del antiguo real minero de Guadalcázar, las cuales constituyen el segundo y tercer ejemplo del corpus aquí analizado. San Pedro Guadalcázar es una fundación de principios del siglo XviI, que se encuentra a 80 kilómetros en dirección noreste de San Luis Potosí, y a poco más de 20 kilómetros de Pozo del Carmen. En este real minero se construyeron dos templos en el siglo XVIII: la parroquia, que es del primer tercio de dicho siglo, en tanto que el templo de la Inmaculada Concepción se erigió a instancias del capitán don Francisco de Mora y Luna, el I7 de noviembre de $1749,{ }^{46}$ justo cuando se levantaba la iglesia de Pozo del Carmen.

En los muros exteriores de ambas iglesias aparecen de nuevo lágrimas esgrafiadas, aunque a diferencia de Pozo del Carmen, el llanto de los muros sirve como telón de fondo de una decoración más compleja. En el templo de la Inmaculada Concepción ésta se concentra en el muro norte y en el poniente (que corresponde al presbiterio) y en el caso de la parroquia, en los muros norte y sur. Desafortunadamente, al igual que en el caso de Pozo del Carmen, el paso del tiempo y el descuido han hecho que estos vestigios se vayan perdiendo, aunque aún es posible identificar algunos de ellos.

Junto a las lágrimas hendidas en los muros del templo de la Inmaculada Concepción encontramos una serie de figuras antropomorfas, algunas coronadas y otras con los brazos en alto; personajes y animales varios que parecen representar perros, serpientes o caballos híbridos (fig. 9). Por el costado del presbiterio la ornamentación se vuelve vegetal, con enormes guirnaldas, escudos y cruces. Tristemente, de los templos que analizo en este trabajo, éste es el más afectado por el descuido y el maltrato del tiempo.

Si la decoración de los muros del templo de la Inmaculada se presenta enriquecida con estos elementos, la de los muros de la parroquia de San Pedro se vuelve más compleja. Además de las lágrimas (fig. Io), se observan composiciones geométricas, algunas formando círculos concéntricos, otras círcu-

46. María Esther Méndez Tobías, Capilla de Nuestra Señora de la Concepción: más que una joya arquitectónica, Guadalcázar, siglo XVIII (Guadalcázar: PACMYC, 2007), 33. 
7. Templo de Nuestra Señora de la Inmaculada Concepción (siglo XVIII), Guadalcázar, San Luis Potosí, México. Foto del autor, 20I3. Conaculta-INAH-MÉX. "Reproducción autorizada por el Instituto Nacional de Antropología e Historia”.

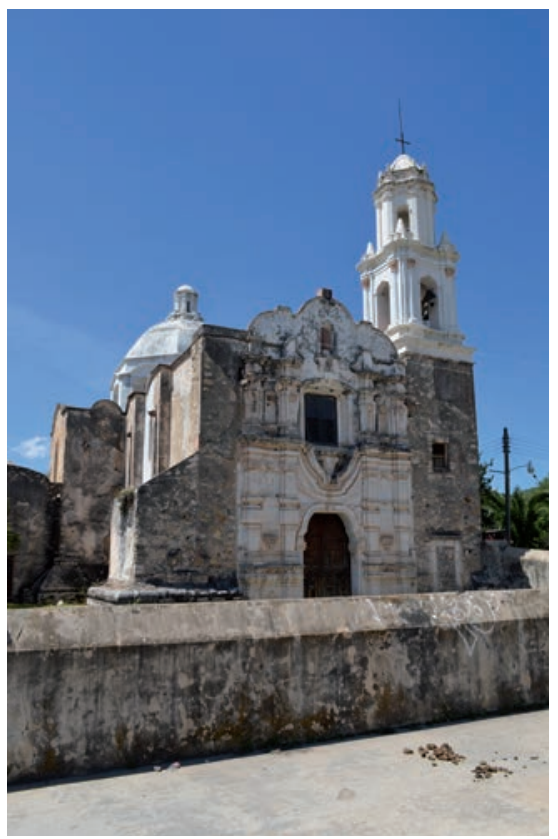

$\oplus$

8. Parroquia de San Pedro (siglo xviII), Guadalcázar, San Luis Potosí, México. Foto del autor, 20I3. Conaculta-INAH-MÉX. "Reproducción autorizada por el Instituto Nacional de Antropología e Historia”.

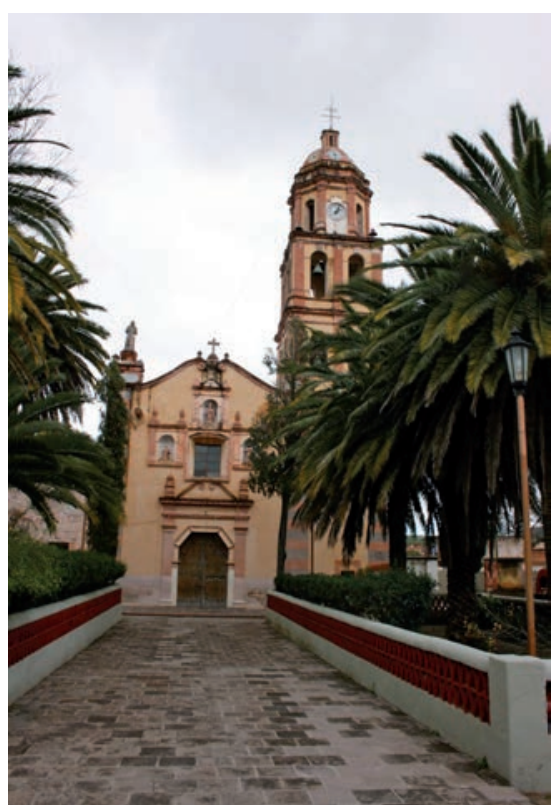




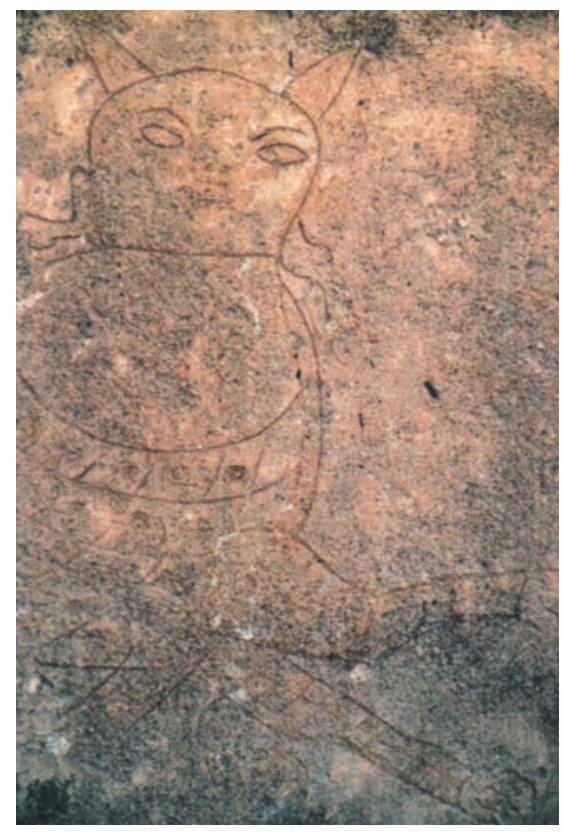

9. Figura zoomorfa. Templo de Nuestra Señora de la Inmaculada Concepción. Foto del autor, 2013.

los intersecados por diagonales y líneas rectas. En torno a los vanos de la nave hay también dibujos hendidos que semejan almenas, coronas y volutas; grutescos y figuras geométricas varias. Sin embargo, más interesantes aún son las figuras antropomorfas y zoomorfas en diferentes posturas y representaciones que aparecen en los muros. Destacan por ejemplo un soldado con armadura y yelmo cerrado, y junto a éste, un natural con arco en mano (fig. II), imágenes de corte militar y caballeresco que hunden sus raíces en el renacimiento español, donde también se representaron en forma de pinturas ${ }^{47}$ y esgrafiados $^{48}$ sobre enlucidos de yeso, y que en este caso alcanzan una reinterpretación que, en virtud de la ingenuidad de su trazo, incluso se podría considerar naíf.

A las figuras antropomorfas se suman animales varios: escorpiones, cerdos, coyotes, aves; pero también representaciones mitológicas como sirenas y centauros (figs. I2, I3 y I4) que resultan típicamente europeos, ${ }^{49}$ aunque ejecu-

47. López Guzmán, Arquitectura mudéjar, 93.

48. Ruiz Alonso, "El esgrafiado en Segovia", 23r.

49. López Guzmán, Arquitectura mudéjar, 90. 


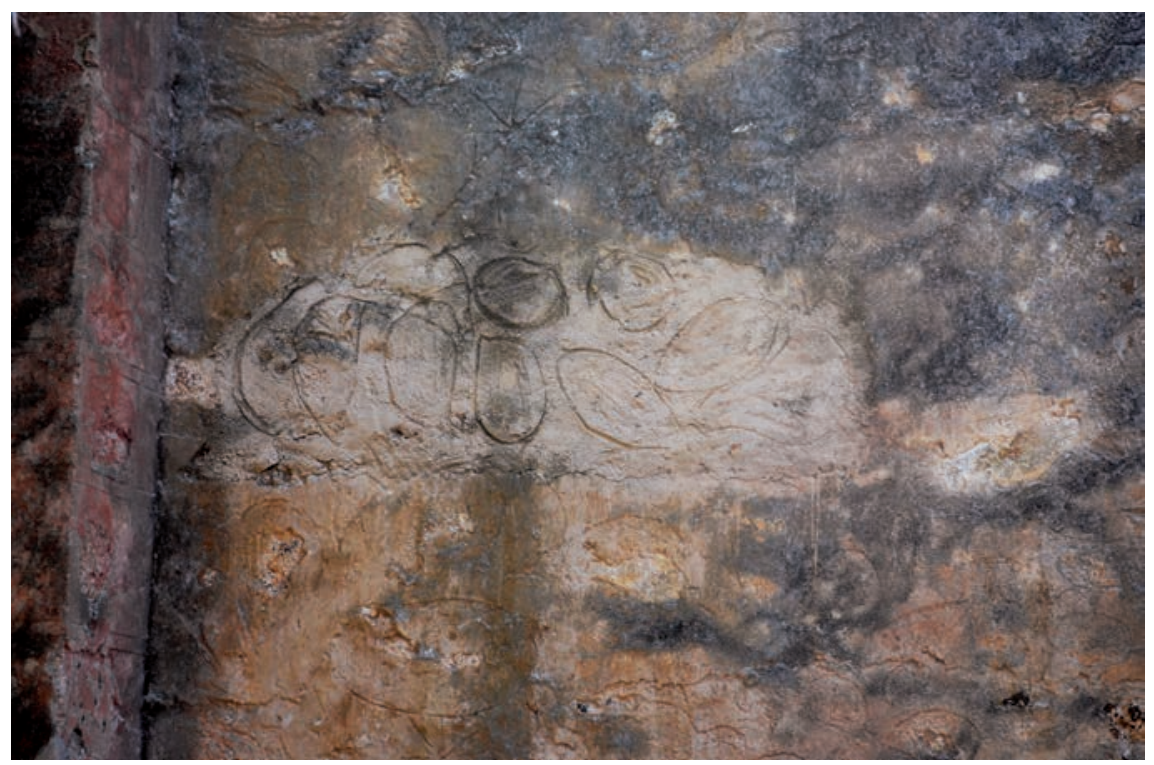

Io. Esgrafiado de lágrima. Parroquia de San Pedro. Foto del autor, 2013.

tados con una técnica de tradición mudéjar y bajo la mano inexperta del trabajador local. En estos muros de construcción novohispana queda manifiesto cómo se hermana una técnica proveniente del mundo andalusí, con una retórica formal claramente española, aderezada sin duda por el imaginario de los naturales que con seguridad trabajaron en su edificación. No me detendré a analizar e interpretar estas figuras, ya que serán ocasión de trabajos siguientes, baste destacar el uso de una técnica y unos patrones figurativos — como son las lágrimas - en estas dos construcciones, heredados del arte mudéjar.

\section{Una herencia mudéjar con escala en la región de Puebla-Tlaxcala}

Para comprender la importancia de los ejemplos existentes en Guadalcázar, se debe mencionar que tales representaciones gráficas tienen sus antecedentes novohispanos en algunas edificaciones del centro de la Nueva España (en los actuales estados de Puebla y Tlaxcala), cuyos ejemplos datan de los siglos Xvi al XVIII. Esta región se caracterizó durante el virreinato por el empleo de técnicas 


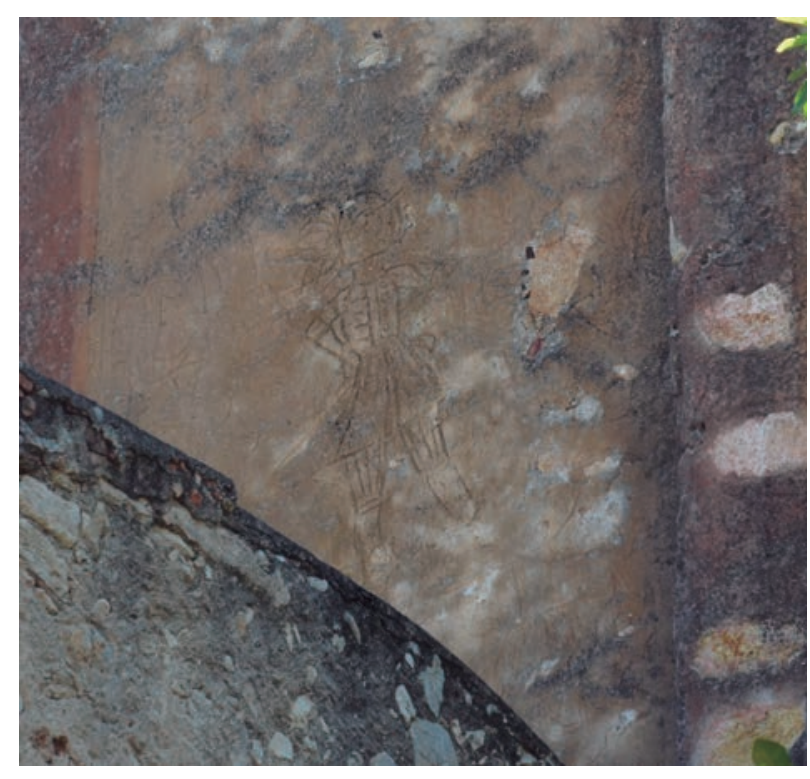

II. Esgrafiado representando un soldado con armadura y yelmo; a la izquierda, representación de un natural con arco y flecha. Parroquia de San Pedro.

Foto del autor, 2013.

y soluciones de herencia mudéjar en sus construcciones; alfarjes tanto en claustros como en capillas abiertas, armaduras y cubiertas artesonadas (Huejotzingo en Puebla y San Francisco de Tlaxcala acaso sean los ejemplos más complejos de este arte en México); $;^{50}$ pero a la par de esta técnica, claramente vistosa, se cultivó otra más económica y que servía para decorar los exteriores.

Compuestas principalmente por figuras antropomorfas, zoomorfas, geométricas, letras, símbolos y grutescos, pero también por representaciones pasionarias, monogramas (Jesús, María, José), águilas bicéfalas, glifos y símbolos prehispánicos, estas formas ornamentaron los muros exteriores de edificaciones religiosas y, en menor escala, de edificios civiles y antiguas haciendas, que se construyeron sobre todo en zonas rurales y semirrurales de esta región. A estas imágenes se les ha llamado en México, coloquialmente, "figuritas de albañiles" ${ }^{I}$ La idea que subyace en este concepto es que las cuadrillas que componían los cuerpos de canteros que trabajaban en una obra (en su mayoría indígenas) dejaban, con anuencia de los sacerdotes, su "sello", tal y como lo

50. López Guzmán, Arquitectura y carpintería, I24.

5I. Francisco Pérez de Salazar Verea, "Figuritas de albañiles", Boletin de Monumentos Históricos, núm. 3 (tercera época) (enero-abril de 2005), 46. 


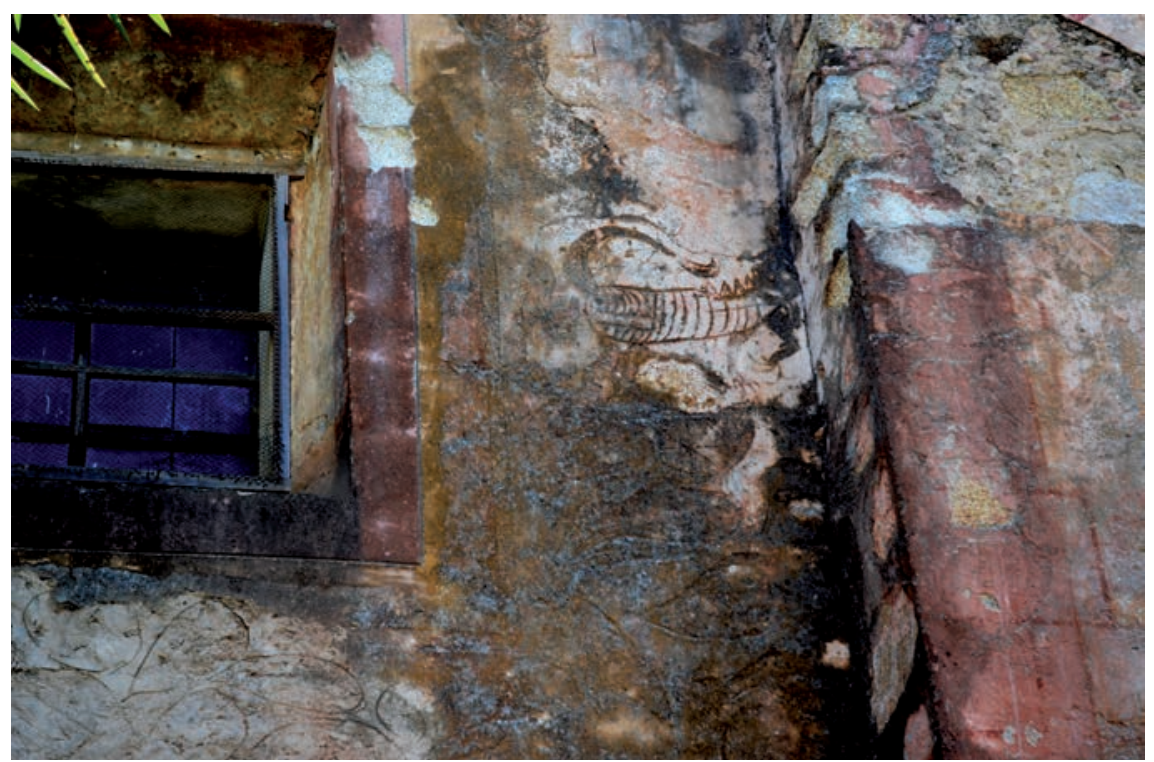

I2. Esgrafiado de lágrima y representación zoomorfa. Parroquia de San Pedro. Foto del autor, 2013.

hacían los canteros de la Europa medieval.52 Difiero de la generalidad que se le ha dado a este concepto e interpretación, toda vez que algunos dibujos hendidos muestran algo más que una simple "seña de identidad", y son en ocasiones, como en los casos ya vistos de Guadalcázar, un corpus de imágenes complejas que deben ser analizadas tanto individualmente como en conjunto para llegar a una interpretación más adecuada.

Ahora bien, la diferencia que existe entre la técnica empleada en la región Puebla-Tlaxcala respecto a la aplicada en Guadalcázar, es que en el caso del centro del virreinato, al esgrafiado inicial de hendiduras sencillas le siguió otra técnica igualmente empleada en la decoración mudéjar y que se conoce en España como "rejuntado",53 mientras que en México se le llama "rajuelado" o "rejoneo". El procedimiento consiste en aplicar trozos pequeños de piedra (guijarros y escoria) sobre un tendel fresco siguiendo al inicio la unión entre

52. Pérez de Salazar Verea, "Figuritas", 46.

53. Ruiz Alonso, "El esgrafiado en Segovia", I87. 


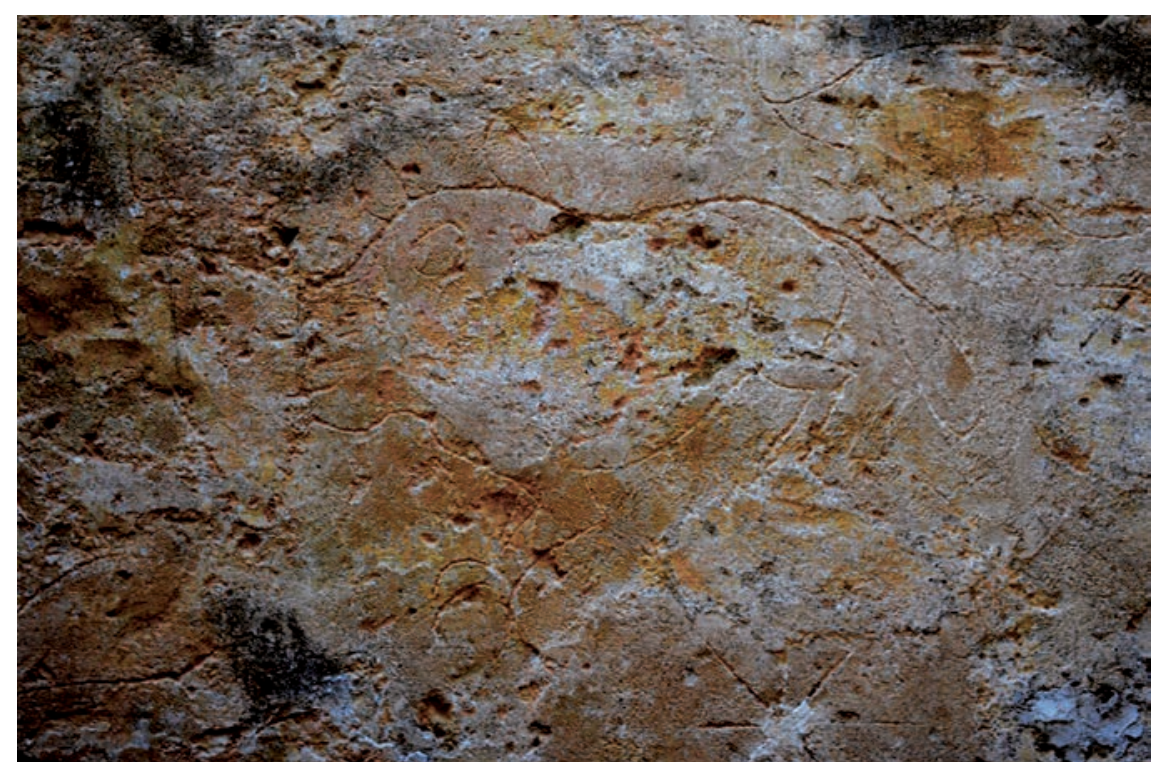

13. Esgrafiado de representación zoomorfa. Parroquia de San Pedro. Foto del autor, 20I3.

piedras, que deriva en un patrón de figuras en forma de lágrima, gota o acorazonadas y posteriormente en patrones figurativos más complejos. Esto pudo evolucionar a su vez del uso de escoria en las junturas selladas de la mampostería, que además de darle un aspecto ornamental, le permitía reducir la aparición de grietas en el momento que fraguara el mortero aplicado. ${ }^{54}$ Así, aunque la técnica del "rejoneo" o "rejuntado" es más compleja, proviene de los mismos procesos empleados para obtener una decoración económica como lo fueron las lágrimas esgrafiadas.

El caso paradigmático del uso de esta técnica es una casa de aparente poca importancia al exterior, pero cuyo interior servirá para ejemplificar lo anterior.

San Luis Tehuiloyocan es una población de la región de Cholula del actual estado de Puebla, la cual se ha caracterizado por el uso de la técnica del "rejoneo" en sus edificaciones religiosas y civiles; es también sede de una de las casas (siglo XviII) en las que no sólo se aprecia con toda precisión el empleo de esta técnica, sino que destaca por el enigmático mensaje cifrado en sus

54. Ruiz Alonso, "El esgrafiado en Segovia", I87-I88. 
I4. Diversas representaciones zoomorfas, antropomorfas y de seres híbridos. Parroquia de San Pedro. Foto del autor, 2013.

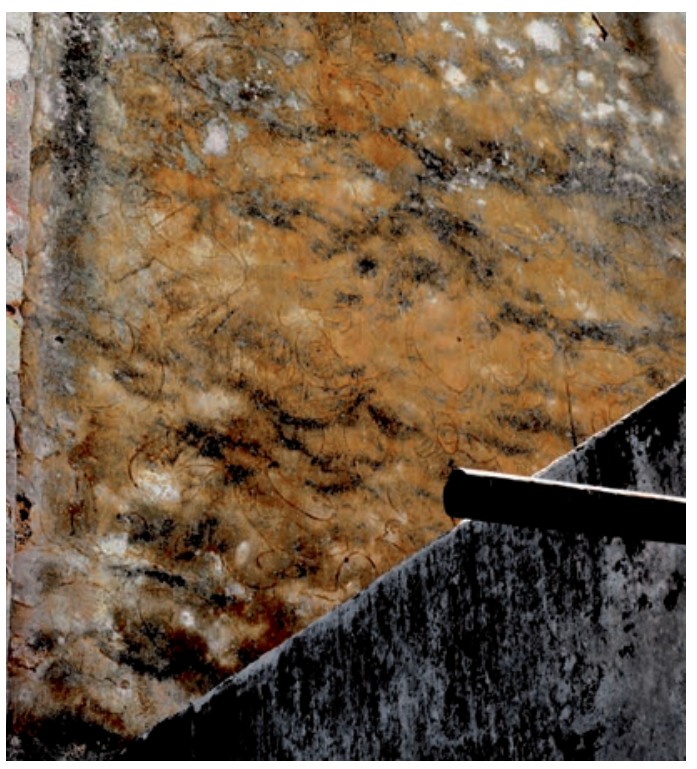

muros. Ubicada en una calle cercana a la plaza principal, la casa en cuestión está construida con adobe, sobre cuyo revoque fresco de los muros de los patios interiores — no visibles para el transeúnte- , se insertaron una serie de piedrecillas que forman un entramado ornamental y figurativo de compleja lectura. Respecto del significado de sus figuras se han hecho análisis muy interesantes, que han permitido descifrar el programa iconográfico representado en estos muros, según los cuales, en dicha casa se observa una vocación de carácter demoniaco. 55 Diversas representaciones y elementos iconográficos, pero en particular un par de simios itifálicos en actitud burlona, ataviados con sombreros coronados por una cruz (fig. I5), han llevado a los investigadores a deducir lo anterior. Lo interesante de este ejemplo para los fines de este trabajo es que la técnica empleada es conocida hoy día por los lugareños, como de mosaicos, figuritas o muñecas; ${ }^{56}$ y si bien en el caso poblano se ha considerado ésta como una

55. José Pascual Buxó, "San Luis Tehuiloyocan: la morada del diablo", Revista de la Universidad Nacional Autónoma de México, núms. 504-505 (enero-febrero, 1993): 59-69; Antonio Terán Bonilla, La guarida del diablo. Lectura iconográfica de la misteriosa casa de Tehuiloyocan, Puebla (México: El Errante, 2013), 69.

56. Terán Bonilla, La guarida del diablo, 77. 


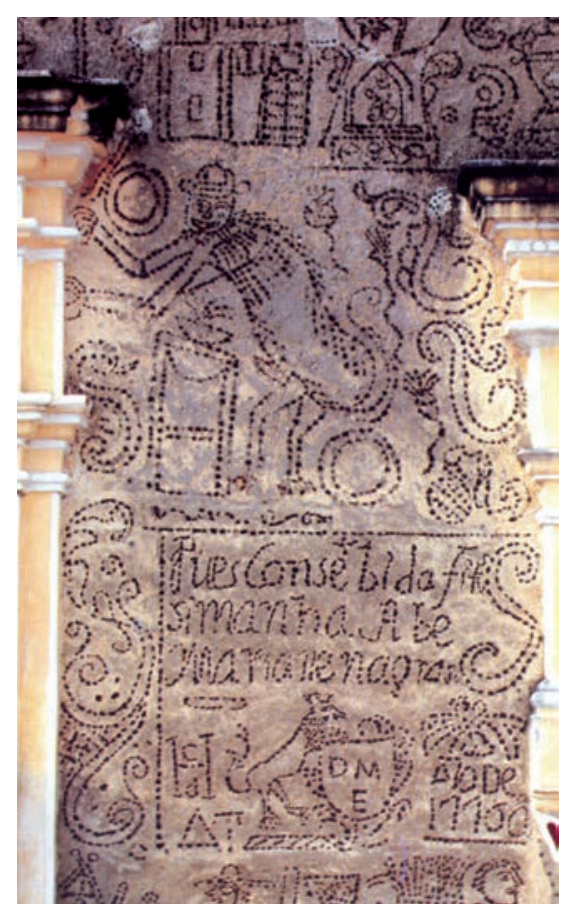

I5. Detalle de decoración con rajuela (simio itifálico) en Casa de Tehuiloyocan, Puebla (siglo XVIII). Foto: J. Antonio Romero F., tomada de Terán Bonilla, La guarida del diablo (vid supra n. 55).

técnica popular propia y característica de la zona rural de Cholula, ${ }^{57}$ también se trata de un recurso que hunde sus raíces en el arte mudéjar, lo cual remite de nuevo al uso de estas soluciones decorativas en las regiones rurales españolas, donde la ornamentación se daba por medio de técnicas económicas.

\section{Sierra de Pinos: lágrimas e imaginería en piedrecillas}

Si en los casos de Pozo del Carmen y Guadalcázar hemos visto el uso de la técnica del esgrafiado de lágrimas y en menor medida el de patrones figurativos complejos por medio de hendiduras sencillas, es en el Real de Sierra de Pinos donde encontramos el uso de la técnica del "rejuntado" característica de la región de Puebla-Tlaxcala, representando tanto lágrimas como figuras antropomorfas, zoomorfas e híbridas. El cuarto ejemplo de este corpus es en conse-

57. Terán Bonilla, La guarida del diablo, 78. 
cuencia la parroquia de españoles dedicada a San Matías, ${ }^{58}$ en la Sierra de Pinos (actual municipio de Zacatecas). Este real minero, ubicado también en el norte del virreinato, fue una población fundada principalmente por indígenas tlaxcaltecas aculturados el I2 de febrero de 1594 bajo el nombre de "Real de Nuestra Señora de la Purísima Concepción de Cuzco y Descubrimiento de Minas que llaman de la Sierra de Pinos", la cual formó parte de la jurisdicción de San Luis Potosí, ${ }^{59}$ hasta que en 1604 , tras una serie de disputas entre las audiencias de la Nueva España y Nueva Galicia se le asignó su jurisdicción a la segunda.

La actual parroquia de San Matías se comenzó a construir en $1680^{6 \circ}$ a instancias de los españoles, y su estructura se modificó hasta el primer tercio del siglo XVIII. En I795 hubo un intento de ampliar el templo de una a tres naves, aunque las obras se detuvieron en $1803,{ }^{61}$ lo que le da ese aspecto de obra inconclusa (fig. 16). Si bien sus muros se encuentran muy deteriorados y algunos de ellos han sido revocados con posterioridad, es posible aún dar cuenta de las figuras en rajuela que los decoran. ${ }^{62}$ Destaca en primer lugar el uso de lágrimas (fig. 17) como en los ejemplos ya analizados, a las que se suman una serie de representaciones figurativas complejas. En el muro oeste, además de figuras zoomórficas, se aprecian parejas de personajes, algunos de ellos masculinos e itifálicos, con tocados (¿nimbos?) triangulares. También sobre este muro, en el tercer tramo arquitectónico, se aprecian representaciones antropomorfas, de las cuales destaca la de un obispo con mitra, báculo, cruz y zapatos de tacón, rodeado por personajes antropomorfos y zoomorfos, así como por el águila bicéfala de los Austria (fig. I8). Al igual que en Guadalcázar, en el resto de los muros del templo se pueden apreciar personajes antropomorfos, aves y cuadrúpedos conviviendo con seres mitológicos, como sirenas. Nuevamente, como no es el objetivo de este trabajo analizar los contenidos iconográficos e iconológicos de estas decoraciones sino la influencia mudéjar en su técnica, no

58. Al haberse fundado principalmente por tlaxcaltecas, los espańoles se vieron en la necesidad de marcar una diferenciación racial que recalara también en el espacio de lo sagrado.

59. Para compararlo con los sitios mencionados en este trabajo, Sierra de Pinos queda a 99 kilómetros de San Luis Potosí, a I50 de Pozo del Carmen y a 186 de Guadalcázar.

6o. Ricardo Acosta Gómez, "Los templos de la Sierra de Pinos, Zacatecas, y sus ministros", Archivos de Historia Potosina 36, IX, núm. 4 (1978): 44-45.

6I. Rubén López Aguilar, Descripción general del templo parroquial de San Matias en Pinos, Zacatecas. Su historia e iconografía (Pinos: Programa de Desarrollo Municipal, 20ro), 28.

62. Rubén López Aguilar ha hecho una descripción más o menos minuciosa del esgrafiado en rajuela de los muros de este templo. López Aguilar, Descripción general del templo, 43-65. Aunque ha confundido el decorado de gotas o lágrimas con "semicírculos y follaje". 


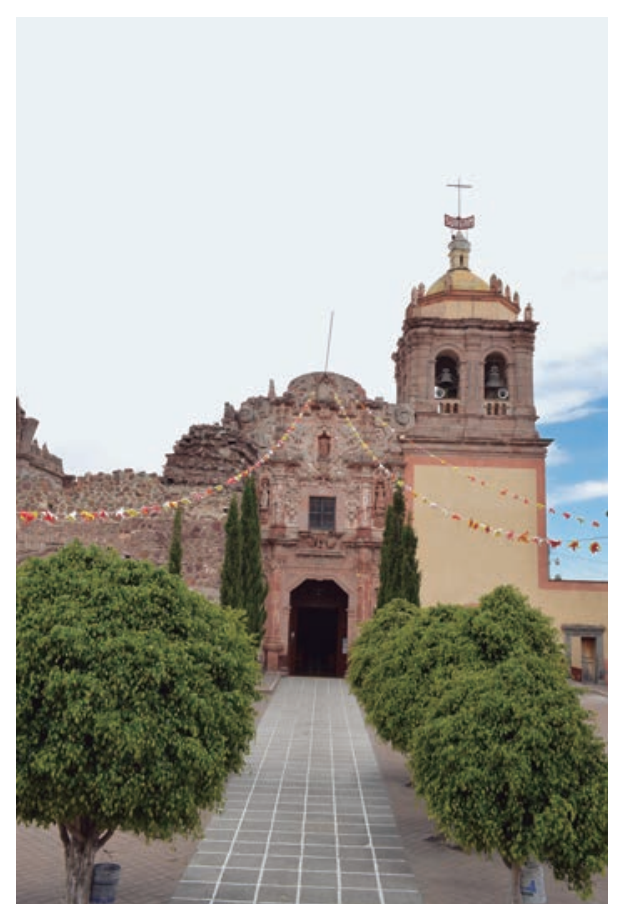

I6. Frontispicio de la parroquia de San Matías (siglo XviII), Pinos, Zacatecas, México. Foto del autor, 2015.

Conaculta-INAH-MÉx. "Reproducción autorizada por el Instituto Nacional de Antropología e Historia”.

me detendré en aventurar siquiera una hipótesis al respecto, sólo subrayaré la necesidad de hacer un estudio a profundidad sobre el particular.

\section{Los templos pleurantes del norte, aproximaciones a su explicación}

Las lágrimas que ornamentan las iglesias aquí analizadas, además de los elementos figurativos que enriquecen los muros de algunas de ellas, hunden sin duda sus raíces en la tradición mudéjar del esgrafiado y el rejuntado que se empleó principalmente por la economía que dichas técnicas suponían. Pero ¿cómo pudo haber llegado hasta el septentrión novohispano, sobre todo en una época tan tardía como lo fue la primera mitad del siglo xvin?

La adopción de esta modalidad decorativa, más allá de la influencia local que se puede apreciar en algunos de sus elementos figurativos, debió ser mediante simples indicaciones verbales por parte de los encargados de las obras, 


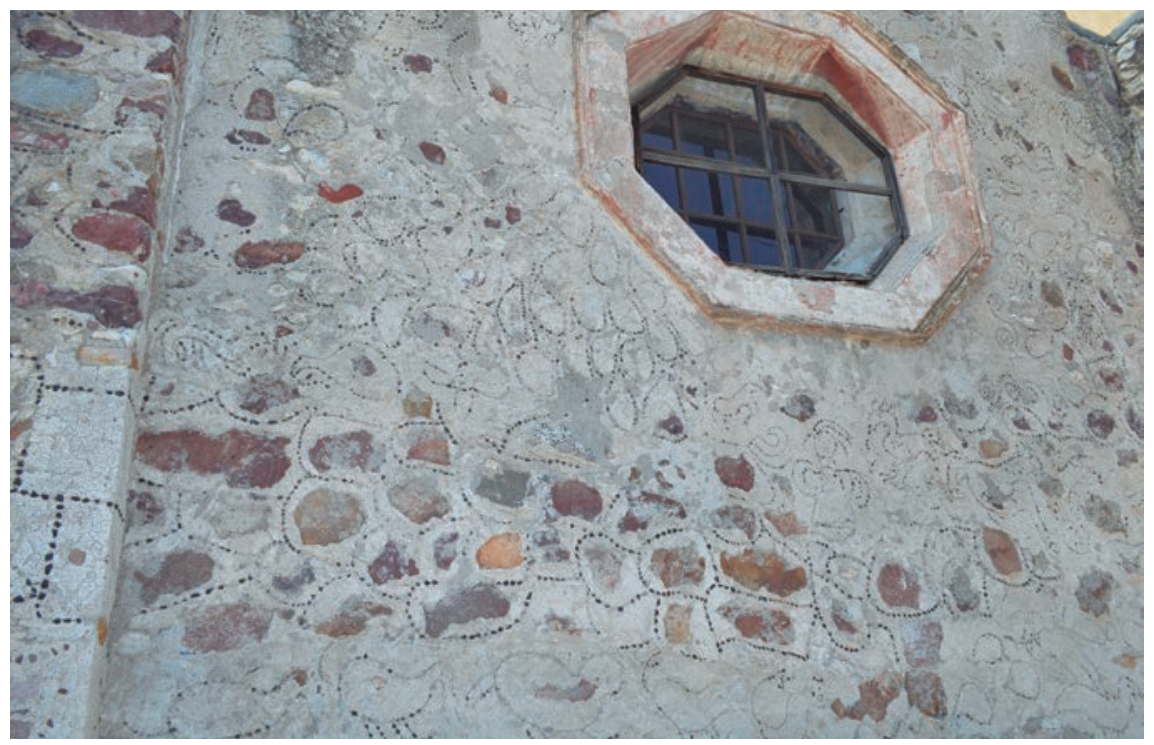

I7. Decoración con rajuela en forma de lágrima. Parroquia de San Matías. Foto del autor, 2015.

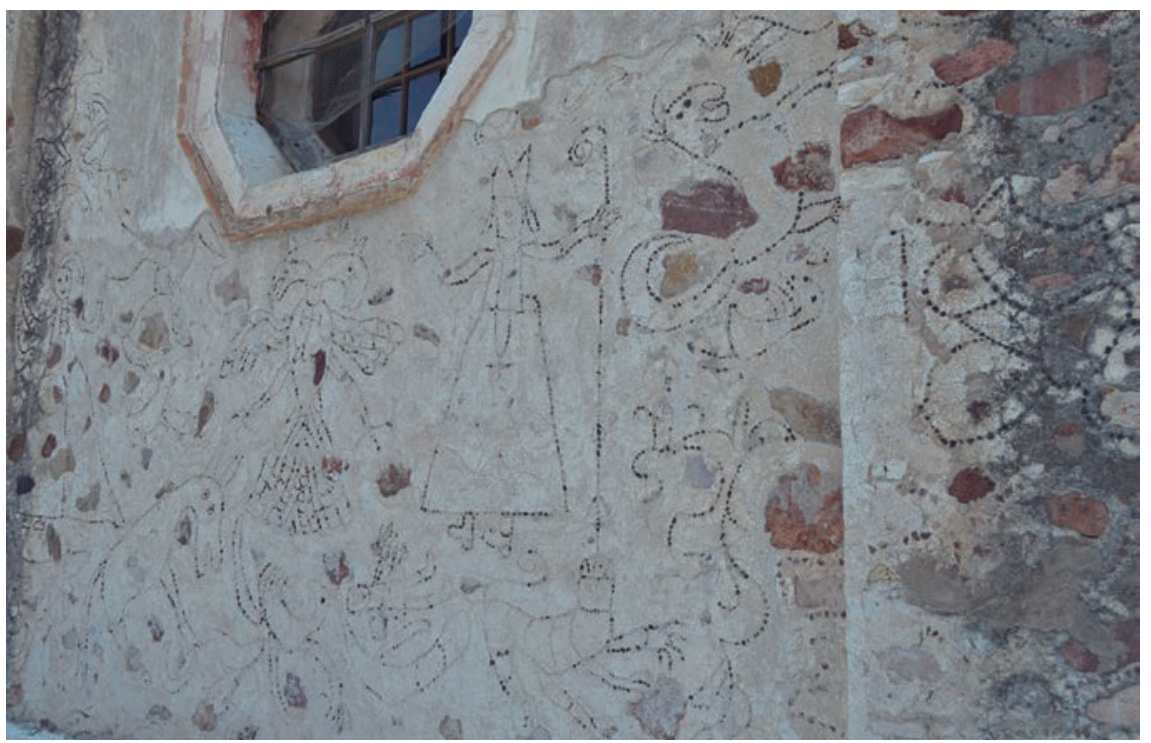

I8. Representación con rajuela de águila bicéfala, figura de obispo, fauna y figuras antropomorfas. Parroquia de San Matías. Foto del autor, 20I5. 
sobre todo en lo que se refiere al uso de lágrimas esgrafiadas como fórmula decorativa. La inexistencia de fuentes librescas de las cuales abrevar para plantear estas decoraciones (como en el caso de la decoración que surge de tratados de arquitectura y de lo blanco), conduce a establecer que fueron producto del intercambio verbal y de la implantación de un gusto o solución traídos de España de manera informal. Es decir, modelos importados de la Península no en forma de tratados o grabados sueltos, sino en la memoria de los constructores quienes a su vez los heredaron como una solución formal que sirvió para cubrir económicamente ciertas necesidades decorativas.

Me parece también lógico pensar que esta pervivencia formal del arte mudéjar encontró un espacio propicio para su evolución en la región de Puebla-Tlaxcala, por ser ésta una de las primeras regiones de asentamiento español, así como por la pronta aculturación a la que se sometió a los naturales. Si se considera que algunos de ellos (quienes formaban parte del mismo proceso de dominio cultural promovido por los Austria) se reubicaron en diferentes regiones del virreinato ${ }^{63}$ como un medio eficaz de apaciguamiento y aculturación a su vez de miembros de otras etnias, y que al hacerlo llevaron consigo los métodos, procesos y técnicas aprendidos de los españoles, se puede entender la llegada de estos técnicos a otras latitudes.

Una posibilidad a considerar es la herencia tlaxcalteca tanto en la jurisdicción de San Luis Potosí como en la de Sierra de Pinos, ya que a finales del siglo Xvi enviaron familias de tlaxcaltecas aculturados para poblar y coadyuvar en el proceso de pacificación de la frontera chichimeca, lo cual explicaría las coincidencias entre las decoraciones de la región Puebla-Tlaxcala y el septentrión novohispano aun y cuando las obras analizadas pertenecen todas a la primera mitad del siglo xviII. Sin embargo, la inexistencia de edificaciones en estas regiones pertenecientes a los siglos anteriores al XVIII impide aventurar si tales soluciones se aplicaron en el siglo precedente. Considero que hace falta realizar más trabajos de rastreo en las zonas rurales del septentrión, los cuales permitirían observar si estos patrones decorativos constituyeron una constante, un vocabulario común en forma de síntesis o si son sólo muestras aisladas de una técnica que sobrevivió al paso de los siglos.

63. A los tlaxcaltecas se les envió principalmente a San Miguel Mexquitic, a Venado (actualmente municipios de San Luis Potosí), al Puesto de San Luis (capital del estado de San Luis Potosí), a Sierra de Pinos, a San Andrés del Teul (actuales municipios de Zacatecas) y a Saltillo (capital del estado de Coahuila). 
Otra opción que puede servir como guía para entender estas manifestaciones artísticas tiene que ver con la mano de obra. La posibilidad de que cuadrillas compuestas por alarifes itinerantes trabajaran en la región de San Luis Potosí y que éstos proviniesen del centro del virreinato explicaría las características decorativas coincidentes entre ambas zonas y los años de construcción de los templos analizados; pues ya se vio que al tiempo que se construía el templo de la Inmaculada en Guadalcázar, se erigía el de Pozo del Carmen. Desafortunadamente también, en ninguno de los casos analizados hay noticias de los constructores y sus cuadrillas, menos aún de las memorias de obra, lo cual deja una laguna pendiente por cubrir. Se debe considerar otro detalle: a diferencia de lo que sucede en Espańa, el esgrafiado en los ejemplos revisados se aplicó únicamente en el exterior, convirtiéndose en una solución que daba salida a la necesidad de ornamentar de forma económica los muros de las iglesias, lo cual hablaría de un trabajo que acaso no demandaba mucha especialización.

Cabe destacar también que he analizado cuatro ejemplos que están en la periferia regional de los grandes centros urbanos (San Luis Potosí, Zacatecas) y que esto quizá explique porqué, mientras en las ciudades se usaban dibujos extraídos de tratados de arquitectura — como los llamados "de perspectiva"-,${ }^{64}$ en las zonas periféricas estudiadas se eligiera usar técnicas menos complejas y más económicas, aunque con posibilidades simbólicas más ricas, como se ha visto. No haber encontrado en lo inmediato más ejemplos se explica en parte porque los enlucidos originales de muchas edificaciones simplemente han desaparecido y con ellos la posibilidad de verificar la presencia de hendiduras y esgrafiados. De manera lamentable, como ya lo señaló David Charles Wright Carr, "los aplanados de mortero de cal, los enlucidos finos y las capas de pintura son eliminados de los elementos arquitectónicos pétreos con demasiada frecuencia, con el pretexto de descubrir la piedra", ${ }^{65}$ perdiéndose así la oportunidad de ampliar este corpus de análisis del septentrión novohispano. Por otro lado, salvo en el caso de la parroquia de San Matías en Sierra de Pinos, está presente la técnica del rajuelado aparente, lo cual, de existir en otras latitudes septentrionales, quizá yace bajo nuevos recubrimientos.

64. Martínez Rosales, El gran teatro, 24I.

65. David Charles Wright Carr, "Los acabados de los monumentos novohispanos y la petrofilia al final del siglo xx", en XXI Coloquio Internacional de Historia del Arte. La abolición del arte, ed. Alberto Dallal (México: Universidad Nacional Autónoma de México-Instituto de Investigaciones Estéticas, 1998), I44. 
No obstante, no puedo sino ofrecer conclusiones provisorias en todos estos sentidos - y con ello abrir la discusión—, ya que reconozco que el corpus analizado resulta pobre en comparación con la vastedad de obras arquitectónicas de la misma época en el septentrión. Acepto, como afirma Rafael López Guzmán, que, al no contar con conjuntos en su totalidad, pero sí en cambio con edificaciones que han llegado muy modificadas a nuestros días, he aplicado el calificativo de pervivencias ${ }^{66}$ a las manifestaciones encontradas en ellas, aunque a diferencia de él, no creo que ello implique poco compromiso de mi parte, sino que revela una condición que, por fragmentaria, no puede seguir otro decurso. La época en la cual se ejecutaron estos conjuntos y sus patrones decorativos, lejos ya del proceso de conquista, aculturación y apropiación del territorio, permite afirmar que llegaron al norte novohispano en el siglo XviII —al cual, insisto, poco se ha vuelto la vista para casos como éste- en forma de pervivencias, como una suerte de reflejo de lo que comenzó siendo en el centro del virreinato una clara y directa influencia mudéjar. Sin embargo, esto no me hace coincidir con López Guzmán en su apreciación de que tales manifestaciones eran "reflejos anquilosados en lo popular", ${ }^{67}$ considero más bien que estas pervivencias seguían siendo opciones estéticas vigentes que daban solución a necesidades específicas, y como prueba de ello está la parroquia de españoles de San Matías en Sierra de Pinos, conjunto de cierta importancia territorial y de clara diferenciación racial, muy alejado de lo que pudiera considerarse como popular.

Haya sido en forma de una tradición transmitida verbalmente o mediante el ejemplo entre las generaciones de constructores que laboraron en esta porción del virreinato, lo cierto es que aun de forma muy sencilla, técnicas y fórmulas decorativas de tradición mudéjar pervivieron hasta llegar al siglo XVIII para aplicarse, ya con las interpretaciones propias de los constructores locales, en edificaciones religiosas del septentrión novohispano. Lo anterior me permite afirmar que sobre los mecanismos de transmisión de saberes y sobre la influencia del arte mudéjar en el Nuevo Mundo y su reinterpretación aún faltan cosas por decir; y que no todas ellas están relacionadas con las grandes obras, sino que en las más sencillas hendiduras que a manera de gotas decoran los muros pleurantes del norte, o en las piedrecillas que en algunos casos los ornamentan, se pueden descubrir también rastros heredados de las raíces andalusíes de España. \$

66. López Guzmán, Arquitectura mudéjar, I9.

67. López Guzmán, Arquitectura mudéjar, 42I. 